\title{
DEHUMANISATION AND OBJECTIFICATION: LESSONS FROM PRAJWAL PARAJULY'S “THE CLEFT”
}

\author{
Susanne Andrea H. Sitohang ${ }^{1}$ \\ ${ }^{1}$ Faculty of Letters and Language Education, Universitas Kristen Indonesia, Jakarta, Indonesia
}
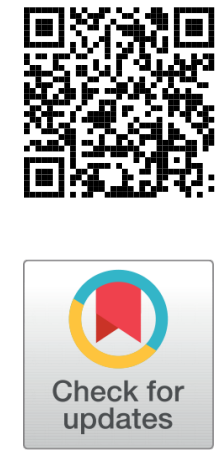

Received 2 May 2021

Accepted 20 May 2021

Published 31 May 2021

Corresponding Author

Susanne Andrea H. Sitohang, susa

nne.sitohang@uki.ac.id

DOI $10.29121 /$

granthaalayah.v9.i5.2021.3942

Funding: This research received no specific grant from any funding agency in the public, commercial, or not-for-profit sectors.

Copyright: (C) 2021 The Author(s). This is an open access article distributed under the terms of the Creative Commons Attribution License, which permits unrestricted use, distribution, and reproduction in any medium, provided the original author and source are credited.

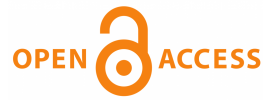

\section{ABSTRACT}

In the current world of globalism and multiculturalism and the face of radicalism and terrorism, it is deemed necessary to prepare our students better to face today's world challenges - to guide students to accept differences among them. Therefore, it is considered necessary to unravel their sense of humanity, being aware of ideas such as objectification and dehumanisation - to introduce students to the idea that we, humans, despite our different beliefs, ideals, political views, and religions, share common feelings, desires, and needs. People come in different shapes, colours, and they all have their deficiencies. How do students deal with the injustice, the inhumanity around them? Do they understand acts of objectification and dehumanisation taking place in the world? Do they understand the concepts? What are their ideas of the two terms related to humanity? Understanding these two keywords will help students unravel within them some sense of humanity. This project highlights efforts to introduce students to a work of literature entitled "The Cleft" written by a Nepalese writer Prajwal Parajuly. The students read the story and are expected to uncover their sense of humanity by understanding the concepts of objectification and dehumanisation. What lessons can students draw after reading the story? After being introduced to the story and the concepts, students are expected to produce their art project as a reflection and reaction to the story and the ideas embedded in it.

Keywords: Humanity, Objectification, Dehumanisation

\section{INTRODUCTION}

Human history has seen how the cruel acts of human have challenged humanity. The world has witnessed different forms of dehumanisation, such as various forms of violence, human rights violations, war crimes, and genocides, massacres, and other kinds of abuse committed by one human to another Kelman (2017), Copelon (2018). Generally, dehumanisation is defined as denying a person's individuality, robbing the individual of the human qualities or the "humanness" inherent in the person Irvine 
(2016), Pokhrel (2016), Albarello and Rubini (2012). Objectification follows any acts of dehumanisation because when one human being dehumanises another human being, he or she is making the victim an object, thus "objectification." A very general explanation states, "...objectification is the act of treating a person, or sometimes an animal, as an object or a thing. It is part of dehumanisation, the act of disavowing the humanity of others" Christie and Noor (2017), Jolley (2011). These two concepts, "dehumanisation" and "objectification", are the core of this paper, as further explained below.

\section{LITERATURE REVIEW}

\subsection{DEHUMANISATION}

"Dehumanisation: An Integrative Review", offers insights on the concept of dehumanization Haslam (2006), Mulkens (2017). This paper mentions that there is still a need for a systematic theoretical basis in defining what dehumanisation means, although we are used to seeing "the denial of full humanness to others, and the cruelty and suffering that accompany it." We may be "guilty" of committing acts of "dehumanisation" unknowingly due to this lack of clear definition.

To understand what "dehumanisation" is, we should understand what "humanness" is. We cannot commit to doing an act of "dehumanisation" when the qualities of "humanness" are denied Culbertson (2007), Cage et al. (2019), Vaes et al. (2012). In addition to the "great" acts of dehumanisation such as genocides, massacres, war crimes and abuse of human rights, Haslam adds that "dehumanisation is an important phenomenon in interpersonal as well as intergroup contexts, occurs outside the domains of violence and conflict, and has social-cognitive dimensions...." Culbertson (2007), Fontesse et al. (2021). There are domains of dehumanisation, namely: ethnicity and race, gender and pornography, disability, medicine and technology, and other domains such as sports, and assessment and teaching Berglund (2006), Methot-Jones (2019). The article further mentions that dehumanisation is an "important consideration or precondition or consequence of violence." Dehumanisation may take softer or "milder, everyday forms."

\subsection{OBJECTIFICATION}

Nussbaum in her work titled "Objectification", offers properties of objectification Nussbaum and Objectification (1995), Beech et al. (2020). A person objectifies another person if he or she treats the other individual in the following ways:

1. Treat a person as a tool for his or her purposes (individuality

2. Deny another person autonomy or self-determination (denial of autonomy

3. Treat a person as lacking in agency or activity (inertness

4. Treat a person as interchangeable with (other objects (fungibility 
5. Treat a person as lacking in boundary integrity and violable" as something that it is permissible to break up, smash, break into." (violability)

6. Treat the person as though they can be owned, bought, or sold (ownership

7. treat the person as though there is no need for concern for their experiences or feelings (denial of subjectivity).

\section{RESEARCH METHOD}

This research is a qualitative project with a content analysis design. Some theories are applied to the text being analysed, in this case, the short story. After the analysis, one reaches a conclusion.

\section{DISCUSSION}

\subsection{DEHUMANISATION AND OBJECTIFICATION}

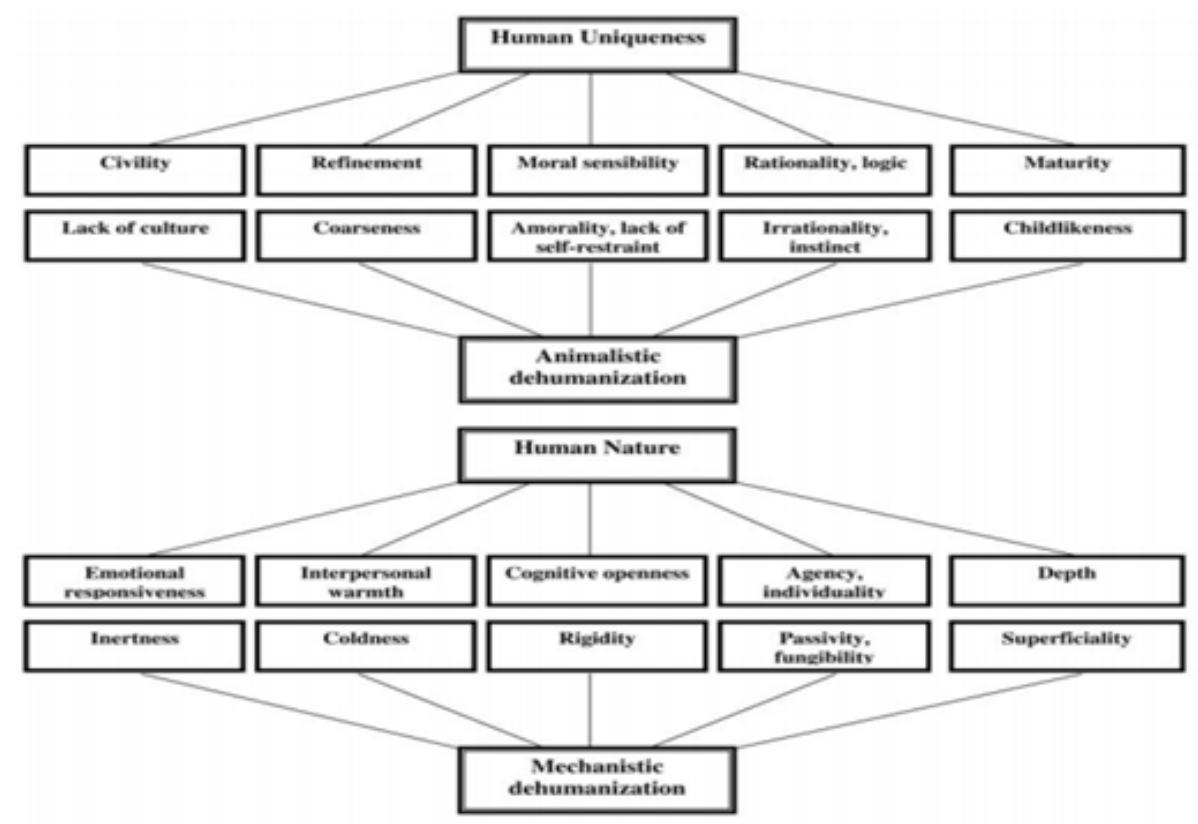

Figure 1. Proposed links between conceptions of humanness and corresponding forms of dehumanization.

As mentioned earlier, dehumanisation occurs when one individual is denied his or her humanness. The following figure describes the connection between the two concepts. It is taken from "Dehumanisation: An Integrative Review". There are two strands of "humanness," namely "Human Uniqueness" which include civility, refinement, moral sensibility, rationality, logic and maturity." Should this type of humanness is denied, the result is "animalistic dehumanisation:" lack of culture, coarseness, amorality, lack of self-restraint, irrationality, instinct, and childlikeness. The second 
strand of "humanness" is "Human Nature" which includes emotional responsiveness, interpersonal warmth, cognitive openness, agency, individuality and depth. Denial of these properties results in mechanistic dehumanisation: inertness, coldness, rigidity, passivity, fungibility, and superficiality.

\section{THE CLEFT}

"The Cleft" is the first story in a collection titled "The Gurkha Daughter: Stories" by Prajwal Parajuly. This collection of eight short stories about the lives of Nepalispeaking people is shortlisted for the Dylan Thomas Prize 2013.

"The Cleft" is a story about Kaali, a servant girl. She was "saved" by a widow named Parvati when Kaali's mother offered her free. Kaali was given away because her mother had too many mouths to feed. Further, Kaali is considered deformed because of her cleft lip and the colour of her skin. This condition leads to verbal abuse and ill-treatment Kaali has to bear. Kaali is considered low by the people around her her mistress, Parvati, Sarita, Parvati sister-in-law, and Sunny, Sarita's son. From the story, a reader witnesses the verbal abuse that Kaali has to take, which probably the reason for Kaali's intention of running away.

\section{DEHUMANISATION AND OBJECTIFICATION IN "THE CLEFT"}

"The Cleft" opens up with Parvati receiving the news that her mother-in-law passed away, and both Parvati and Kaali perched upon the stairs leading to the house while Kaali treated Parvati's hair. Right from the start, we witness how seemingly cruel Parvati treats Kaali. Parvati mentions, "Your name is Kaali, you dark girl, and your brain is as dark as your face. You understand nothing."It is the start of many dehumanisation acts and objectification in daily life of a servant girl, as we can see from the list of insults below:

a. "Your name is Kaali, you dark girl, and your brain is as dark as your face.You understand nothing."

b. "It's a good thing you've found employment here, Kaali. With the way you think, you'd be thrown out of everywhere else. Not to forget the way you look-black as coal and those grotesque lips. Were my husband alive, he'd have kicked you out already."

c. "Parvati turned back to look at the servant's lip. Kaali's teeth protruded from under the cleft, and she looked like a mouse ready to nibble on a piece of cheese. Parvati touched the deformity with her fingers.

d. "That's the reason you still have a home, Kaali-you never complain. You wash plates like a blind woman-just today I had to rewash three plates-and you mop like a baby. You aren't good at anything and look like that, but I'll put up with you because of your attitude."

e. "That's because you can't do anything efficiently, didn't I tell you?" Parvati said, adding in a resigned voice,...." 
f. "Why? You want a plane ride, you greedy girl?"

g. "If you stay with us for four more years, maybe we'll arrange for some surgery. Will that make you happy?"

"And school?" She spotted another louse but didn't pursue it."

"Why go to school?" Parvati looked straight at Kaali. "Look, I am high school pass, and yet I stay at home doing nothing. You need not go to school. Learn the basics from me. Show some initiative. Bring your notebook and pencil when I am free. But why would you? You're too busy running around Battisputalli with the neighbourhood children, too busy imagining what a beauty you will turn into after the surgery. Remember, the surgery only takes place after four years, and I shall take into account every misbehavior of yours before I decide on it."

h. "You're so stupid. Are you the one with the bad lip?"

"Yes."

i. "Of course, you are, you fool...."

j. "You know nothing. How long have you been with us? Four years? You came as a baby and still have the brains of a baby."

k. "Yes, yes, four years, five years-what's the difference? You were nothing but bones when we brought you in. Your mother didn't want another girl child."

l. "Parvati had narrated the story before. In fact, Kaali heard it on a weekly basis. Her mother, pressured by the growing number of mouths to feed, decided to chop off the weakest link in her family. It had to be a girl, and Kaali, with her cleft lip, was the most useless of them all. She was a sickly child, a liability who'd never be an asset. When a young widow came to their shanty in Dooars, on the India-Bhutan border, looking for a servant girl, Kaali's mother offered her for free."

m. "Your brothers and sisters hated you, and I shouldn't blame them, for you were scary to look at."

n. "You don't even remember how I ran after your eight-year-old self because you had instinctively guessed I was taking you away. What an imbecile-you had no clue you were going to lead a better life with me. You don't remember how many spoons of sugar I need. You don't even remember the insults Sarita just heaped on you. You remember nothing. What do I do with you?"

o. "And you didn't have any underwear on, you uncivilised being-how often have I told you about the panties you wore on your head after I bought you a pair? You thought they didn't fit. Look at how far you've come, but your brains are still the same-you're still Adivasi in your mentality. Adivasi (indigenous)"

p. "Parvati brought up the underwear episode so frequently that Kaali no longer associated it with shame".

q. "Always thinking of food, you khanchuwee. It must be the extra hole in your lip that makes you hungry all the time."

r. "Kaali, after shrugging off a stinging remark about her ugliness from Sarita's teenage son, was now safely on top of all the luggage bags in the trunk." 
s. "Why don't you pee standing up like a man, Kaali?" Sunny shouted from the other side of the road. "You look like a boy, and you should pee like a boy." The comment provoked a guffaw from the quiet driver."

t. "Did you eat like a pig, Kaali?" Parvati asked.

u. "Now you're talking like Kaali. She's been asking to be sent to school for some time now."

"Why don't you? She doesn't do a lot during the day."

"What will she do with an education and that face? It will all be a wasted effort."

"She wouldn't bother you during the day," Sarita countered.

"I want her home during the day."

“She keeps you company, doesn't she? I always knew you were very attached to her."

v. "That was just stupid Kaali," Sarita said to her husband on the phone. "Can't even stand straight. All right, I have to go now. We are almost here."

w. "I keep forgetting you went singing with that terrible voice of yours from house to house. Maybe people didn't throw you out because they were feeling bighearted during the festival season."

A closer look at the insults will clearly show that dehumanisation and objectification are committed in the story.

\section{DEHUMANISATION AND OBJECTIFICATION: LESSONS FROM PRAJWAL PARAJULY'S "THE CLEFT"}

"The Cleft" is a great vehicle to introduce students to the ideas of dehumanisation and objectification. The story is so rich in samples of acts of abuse committed to a simple servant girl by her mistress. The story is relevant, especially in the Indonesian's setting, as Indonesians also have hired 'assistants' in their houses. Indonesians hire young girls to do the everyday chores with low payment. These 'assistants' work from morning until night and most probably receive the treatment that Kaali receives. The students in our classes may have committed acts of dehumanisation and objectification in one way or another. It is the reason why we need to introduce the ideas of dehumanisation and objectification to them.

There are many ways for teachers to use this story and encourage the students to realise the gravity of dehumanisation and objectification committed in everyday lives and communication. Teachers can first encourage students to understand dehumanisation and objectification and then have them read the stories and identify utterances and acts showing dehumanisation and objectification taking place in the story (this can be done individually and in groups). After that, the students can classify the dehumanisation and objectification of each utterance and incident show and exemplify. As a final activity, the students should reflect to see how relevant the story is and think about their behaviour concerning the ideas of dehumanisation and objectification, whether somehow, they, without realising it, have committed acts of dehu- 
manisation and objectification. It is hoped that after that realisation, they will be more cautious in treating the people around them, significantly people "lower" than them.

\section{CONCLUSION}

After analysing the short story, one can conclude that being aware that we, too, may dehumanise and objectify, unknowingly, will keep us alert to always carefully of how we treat the people around us. Of course, this will lead to a more peaceful and harmonious world. Therefore, it is essential to include short stories or works of literature depicting humanity to students so that they are sensitive to different ways one can dehumanise and objectify fellow human beings.

\section{REFERENCES}

Albarello, F., \& Rubini, M. (2012). Reducing dehumanisation outcomes towards Blacks: The role of multiple categorisation and of human identity. European Journal of Social Psychology, 42(7), 875-882. Retrieved from https://dx.doi.org/10.1002/ejsp.1902 10 $.1002 /$ ejsp.1902

Beech, O. D., Kaufmann, L., \& Anderson, J. (2020). A Systematic Literature Review Exploring Objectification and Motherhood. Psychology of Women Quarterly, 44(4), 521-538. Retrieved from https://dx.doi.org/10.1177/0361684320949810 $10.1177 /$ 0361684320949810

Berglund, J. (2006). Cannibal Fictions: American Explorations Of Colonialism, Race, Gender, And Sexuality. In and others (Ed.), . Univ Of Wisconsin Press.

Cage, E., Monaco, J. D., \& Newell, V. (2019). Understanding, attitudes and dehumanisation towards autistic people. Autism, 23(6), 1373-1383. Retrieved from https://dx.doi.org/ $10.1177 / 136236131881129010.1177 / 1362361318811290$

Christie, D. J., \& Noor, N. M. (2017). Humanising And Dehumanising The Other: Ethnic Conflict In Malaysia. In Enlarging The Scope Of Peace Psychology (pp. 109-157). Springer.

Copelon, R. (2018). Gendered War Crimes: Reconceptualizing Rape In Time Of War. Women's Rights Human Rights, 197-214.

Culbertson, L. (2007). 'Human-ness', 'dehumanisation' and performance enhancement. Sport, Ethics and Philosophy, 1(2), 195-217. Retrieved from https://dx.doi.org/10.1080/ $1751132070143987710.1080 / 17511320701439877$

Fontesse, S., Stinglhamber, F., Demoulin, S., Timary, P., \& Maurage, P. (2021). Selfdehumanisation in severe alcohol use disorder: Links with self-stigma and environmental satisfaction. International Journal of Psychology. Retrieved from https://dx.doi .org/10.1002/ijop.12774 10.1002/ijop.12774

Haslam, N. (2006). Dehumanization: An Integrative Review. Personality And Social Psychology Review, 10(3), 252-264.

Irvine, A. (2016). Recycled Alterity: Familiar Dehumanisation In The Contemporary Fiction of Genetic Posthumanism (Doctoral Dissertation, Researchspace@ Auckland).

Jolley, D. R. (2011). A Person Is A Person Through Other Persons.

Kelman, H. C. (2017). Violence Without Moral Restraint: Reflections On The Dehumanization Of Victims And Victimizers. The Criminology of War, 145-181. 
Methot-Jones, T. (2019). Psychopathy, Dehumanization, and Sexist and Violent Attitudes Towards Women. In and others (Ed.), Google Books. Brock University.

Mulkens, S. F. (2017). An Analysis Of How Dehumanization Affects The Lives Of Refugees In Two Different Refugee Camps/Centers (Unpublished master's thesis). The Dehumanization Of Refugees: A Framework.

Nussbaum, M. C., \& Objectification. (1995). Philosophy And Public Affairs; Fall.

Pokhrel, T. (2016). Exploration Of Self: A Third-World Feminist Reading In Parajuly's The Gurkha's Daughter (Doctoral Dissertation).

Vaes, J., Leyens, J.-P., Paladino, M. P., \& Miranda, M. P. (2012). We are human, they are not: Driving forces behind outgroup dehumanisation and the humanisation of the ingroup. European Review of Social Psychology, 23(1), 64-106. Retrieved from https://dx.doi.org/ $10.1080 / 10463283.2012 .66525010 .1080 / 10463283.2012 .665250$ 